\title{
Effectiveness of Communication Strategies used in Creating Awareness and Uptake of Food Quality and Safety Standards in the Informal Market Outlets of Camel Suusa and Nyirinyiri
}

\author{
Madete S. K. Pauline ${ }^{1}$, Bebe O. Bockline ${ }^{2}$, Matofari W. Joseph ${ }^{1}$, Muliro S. Patrick ${ }^{1}$ \\ ${ }^{1}$ Department of Dairy and Food Science and Technology, Egerton University, Nakuru, Kenya \\ ${ }^{2}$ Department of Animal Sciences, Egerton University, Nakuru, Kenya
}

Email address:

mdtpauline@yahoo.com (M. Pauline)

To cite this article:

Madete S. K Pauline, Bebe O. Bockline, Matofari W. Joseph, Muliro S. Patrick. Effectiveness of Communication Strategies used in Creating Awareness and Uptake of Food Quality and Safety Standards in the Informal Market Outlets of Camel Suusa and Nyirinyiri. Agriculture, Forestry and Fisheries. Vol. 4, No. 3, 2015, pp. 83-86. doi: 10.11648/j.aff.20150403.11

\begin{abstract}
The Nyirinyiri and Suusa products from camel meat and milk processed by pastoral women using indigenous knowledge and traded in the informal markets presents opportunities to enhance household food security and income and also health benefits to consumers. However, safety and quality concerns by consumers are market barriers, especially acceptability beyond the traditional camel eating communities and in urban niche markets. It is possible to break this market barrier with effective communication of the food safety and quality standards but there exist knowledge gaps on the extent to which use of seminars and trainings, media briefs, radios, television and manuals increase awareness and uptake of the food standards and benefits to actors in the informal food markets. This study therefore identified the effectiveness of communication strategies used in promoting awareness and uptake of food quality and safety standards in the informal market outlet. Survey, Focus Group Discussion and Participatory appraisal of actors along the value chain were the methods used in data collection. The results showed that communication strategies in place were meant for the formal market hence the camel Suusa and Nyirinyiri chain actors gave the perceived effectiveness of the communication strategies if they were to be for the informal market outlet for promote acceptance and access for Suusa and Nyirinyiri in the high value markets.
\end{abstract}

Keywords: Food Quality and Safety, Informal Markets, Communication, Consumer Concern

\section{Introduction}

Safer food can generate both health and wealth for the poor. Wanyoike et al., (2008) and Kaitibei et al. (2010) noted that products such as Suusa and Nyirinyiri do not exploit higher market value due to their inability to meet safety and quality standards. Food quality and safety are the totality of characteristics of the food products that bear on their ability to satisfy all legal, customer and consumer requirements (Will and Guenther, 2007). Quality includes all product attributes that influence its value to consumers, whereas safety includes all measures intended to protect human health (Nelson, 2005).

Women play an important role in activities dealing with livestock management, transformation and marketing (IFAD, 2009). Pastoral women's human capital includes their knowledge and skills on animal health and husbandry, livestock management, natural resource management and environmental conservation, much of which is unrecognized both by outsiders and sometimes within their own societies. Their human capital may however be limited by their lack of knowledge of the market economy and their rights under national law. In spite therefore of their indigenous knowledge, strong capacities and resilience, pastoral women begin life with less human capital than their male counterparts and rarely get the opportunity to redress this balance (Watson, 2010). In Kenya food quality and safety standards are generated by two main regulators; Kenya Bureau of Standards (KEBS) and Kenya Dairy Board (KDB). Thereafter, the generated standards are disseminated using different communication strategies to the formal and informal market outlets. 
The information shared by the regulators are on hygienic and sanitation, functional food properties, packaging, health attributes to consumers, shelf life, aroma, flavour, texture (FAO/ WHO, 2005). Although food safety and quality standards information is available from various sources, awareness is likely to be low because the information dissemination is not demand driven. The general packaging and medium of communication are unlikely to be appropriate to the needs of the users in the informal market because of barriers with access to the channels of choice by the regulators. There is however knowledge gaps about the extent to which these information sharing strategies can influence awareness and uptake and benefits of food quality and safety actions in the informal markets where pastoral women process and trade Suusa and Nyirinyiri.

\section{Methodology}

This study used survey, Focus Group Discussions (FGD) and participatory rapid appraisal approaches to sample actors along the camel Suusa and Nyirinyiri value chains in Isiolo, Marsabit and Nairobi (Eastleigh) where consumption of camel products is predominant in Kenya. Sampling targeted the value chain regulators, supporters and operators to identify communication strategies which they use in creating awareness on food safety and quality standards. Data collected was subjected to cross tabulation, Chi-square test statistics and post hoc Anova.

\section{Results and Discussion}

Survey results could not identify any communication strategy specifically targeted to promoting awareness and uptake of food safety and quality standards in the informal market outlets of camel Suusa and Nyirinyiri. The communication strategies mentioned in Figure 5 are best suited to communicating formal food quality and safety standards as part of risk communication in formal market outlets. This calls for an in-depth knowledge of target audiences, which include their level of awareness and understanding of food safety issues; their attitudes to food in general and food safety in particular; the possible impact of communications on behaviour; and the appropriate channels for effective dissemination of messages (FAO/WHO, 2002). This is because the camel Suusa and Nyirinyiri is produced using indigenous knowledge.

Table 1 highlights the magnitude of effectiveness of communication strategies as rated by value chain actors of camel Suusa and Nyirinyiri The rating suggest that all actors consider mass media equally effective but they differ on the effectives of print and electronic media and direct methods. These points to mass media as being an acceptable communication strategy among all actors for communicating food safety and quality standards.

Table 1. Mean \pm SD rating ( $1=$ High; $5=$ low) of effectiveness of communication strategies in the informal market outlet of camel Suusa and Nyirinyiri.

\begin{tabular}{llllll}
\hline Chain actors & Sample (n) & Mass media & Print media & Electronic media \\
\hline Producers & 12 & $1.58 \pm 0.79$ & $4.17 \pm 1.12^{\mathrm{b}}$ & $4.17 \pm 1.11^{\mathrm{ab}}$ & Direct methods \\
Processors & 10 & $1.80 \pm 0.78$ & $2.60 \pm 1.17^{\mathrm{a}}$ & $4.40 \pm 0.52^{\mathrm{b}}$ & $2.40 \pm 1.27^{\mathrm{b}}$ \\
Transporters & 8 & $2.13 \pm 1.60$ & $3.25 \pm 1.17^{\mathrm{ab}}$ & $4.25 \pm 0.71^{\mathrm{b}}$ & $1.13 \pm 0.35^{\mathrm{a}}$ \\
Marketers & 10 & $2.90 \pm 1.25$ & $3.40 \pm 0.52^{\mathrm{ab}}$ & $3.20 \pm 0.63^{\mathrm{a}}$ & $1.70 \pm 0.68^{\mathrm{ab}}$ \\
Consumers & 30 & $2.37 \pm 1.89$ & $2.17 \pm 1.29^{\mathrm{a}}$ & $3.70 \pm 0.95^{\mathrm{ab}}$ & $2.63 \pm 1.19^{\mathrm{b}}$ \\
F & & 2.276 & 7.492 & 3.409 & 0.014 \\
Sig & & 0.070 & 0.00 & 0.001 & 0.001 \\
\hline
\end{tabular}

Table 2 summarizes the proportional responses by actors when actors asked of which communication strategy would (Table II) be the most effective in promoting uptake of food quality and safety standards. Differences were noticeable among producers and consumers $(\mathrm{p}<0.05)$ but not among processors, transporters or marketers $(\mathrm{p}>0.05)$. Among producers, majority $(66.7 \%)$ indicated direct method was the most effective strategy while mass media was the most effective strategy for majority $(56.7 \%)$ of the consumers. Results points to need for use of diverse communication strategies to reach wider audience of the actors, for they express different preferences.

Table 2. Most effective communication strategies to promote awareness and uptake of food safety and quality standards among actors of the informal market outlet (\% response).

\begin{tabular}{llllll}
\hline Communication strategies & Producers & Processors & Transporters & Marketers & Consumer \\
\hline Mass media & 25 & 40 & 25 & 80 & 56.7 \\
Print media & 8.3 & 10 & 12.5 & 0.0 & 0.0 \\
Electronic media & 0.0 & 0.0 & 0.0 & 0.0 & 6.7 \\
Direct methods & 66.7 & 50 & 62.5 & 20 & 36.7 \\
Sample size (n) & 12 & 10 & 8 & 10 & 30 \\
Chi- square value & 6.500 & 2.600 & 3.2500 & 3.600 & 11.400 \\
P value & $0.039^{*}$ & 0.273 & 0.197 & 0.058 & $0.003^{*}$ \\
\hline
\end{tabular}

Figure 1 elaborates the effectiveness of communication strategies per the respondent feedback $(n=70)$ indicating that about a third $(35.7 \%)$ of the actors found mass media to be more effective in communication of food quality and safety standards in the informal market outlet. Direct methods had about three quarters $(75.7 \%)$ of the respondents citing it as most effective compared to print media and electronic media (5.7\%) respectively, hence, direct methods having the overall 
effect as the most effective communication strategy for promoting awareness and uptake of food quality and safety standards in the informal market outlet of camel Suusa and Nyirinyiri.

Actors along the camel Suusa and Nyirinyiri value chain preferred direct methods (Figure 1) because it allows direct communication between actors and information service providers. Direct methods are most effective among the actors as it is easy to seek their audience. Direct methods alone are not enough in emphasizing on adoption of food quality and safety standards in the informal market outlet yet, in order to reach high value market producers and processors are under high pressure to meet the required standards with an aim of building consumer (pastoralist and non- pastoralist) confidence and ensure safety yet they lack relevant and crucial information on food safety and quality standards (APCAEM, 2008). This calls for strengthening of other communication strategies by the regulators and information service providers in creating awareness and uptake of food quality and safety standards.

Mass media was more effective among camel Suusa and Nyirinyiri owing to the fact that radios are in many households and are portable. Mass media (radio) remains the most powerful, favorite and yet cheapest tool because information is conveyed in the simplest form yet the information is for the formal market. Mass media comes in handy as the pastoral women processors can listen to it even while doing other household chores if broadcast is in local language.

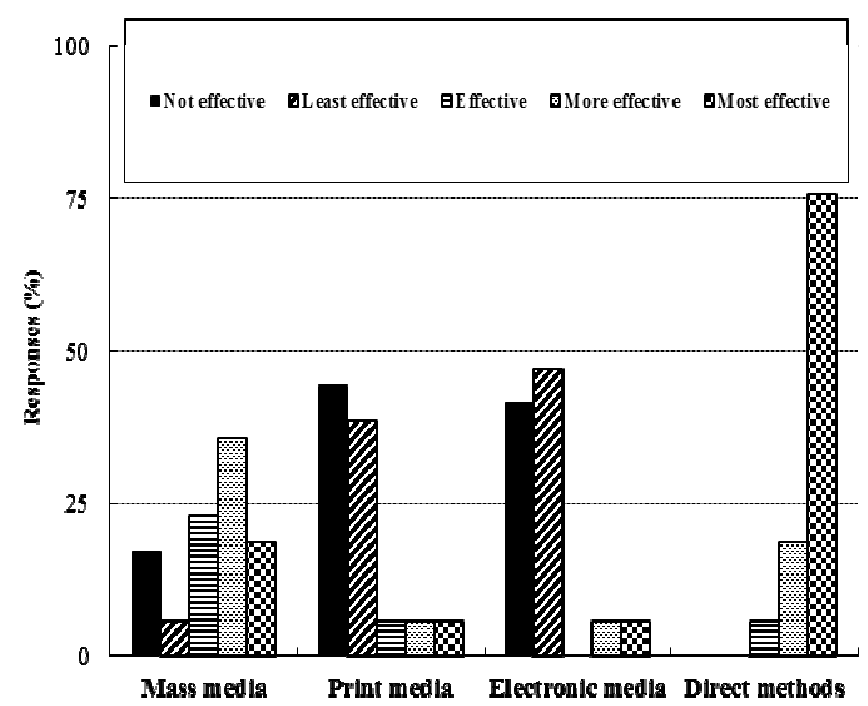

Figure 1. Effectiveness of communication strategies used in promoting awareness and uptake of food quality and safety standards in the informal market outlet of camel Suusa and Nyirinyiri.

Electronic media includes the use of ICT and the actors have found mobile phones very important in getting information on market prices and customer information, delivery and payment of goods. The analysis implies that the use of ICT is yet to be embraced in communicating food quality and safety standards in the informal market of Suusa and Nyirinyiri. The ICT industry is rapidly growing hence the need to embrace technology and promote production of safe and quality food for consumer and pastoral women benefit. Electronic media is being used by pastoral women to communicate with herders, transporters, cooperatives and customers in Nairobi. This is done to ensure that the product reaches the market in good time. Regulators thus need to incorporate the use of mobile phones in communicating food quality and safety standards in the informal market of camel Suusa and Nyirinyiri. Use of radio among the pastoralists is not common as they move up and down and don't have time to listen to it. In the informal market of Suusa and Nyirinyiri use of radio is not very effective as many of them don't listen to radio due to communication barrier and limited frequency of disseminating information.

\section{Conclusion and Recommendation}

The effectiveness of communication strategies varied among the chain actors with direct methods being most preferred followed by mass media. Print media and electronic media ranked least effective communication strategy among the chain actors as it was not preferred because of complex language and being non informative. Appropriate ways of strengthening communication of food quality and safety standards are known but policy remains a key issue because the standards in place are for international markets and not national and informal markets. Policy review was majorly suggested by regulators so as to develop standards for informal market outlet, use of vernacular FM radios and increased frequency of information on food quality and safety standards were the major options given by the actors of Suusa and Nyirinyiri value chain.

There is therefore need for reviewing formal communication strategies with potential to reaching more actors in the informal markets of Indigenous Knowledge Food Products (IKFP). With increased outreach there is a perceived benefit for both pastoral women processors and consumers. This calls for participatory risk analysis, risk management and risk communication so that the right standards are disseminated and linked to the most effective communication strategies with ICT adoption being key in creating awareness and promoting uptake of food quality and safety standards in the informal market outlets.

\section{Acknowledgements}

This work was supported by a grant from RUFORUM which the authors are grateful to. The authors would also like to thank Egerton University and Pastoral women in ASAL areas of Isiolo and Marsabit Kenya.

\section{References}

[1] APCAEM. (2008). Food safety issues in Agriculture trade, policy brief, issue no.3. www.unapcaem.org/publication/epolicybrief.pdf. Retrieved on 12/08/2012. 
[2] FAO/WHO. (2002). Post- harvest technology and food quality. Part 6.Science and technology for sustainable development FAO/WHO. Joint FAO/WHO Food Standards Programme Report of the Sixteenth Session of FAO/WHO Coordinating Committee for Africa, Codex Alimentarius Commission FAO. Rome. 25 - 28 January 2005.

[3] FAO/WHO. (2005). Assuring food safety and quality. Guidelines For strengthening national control.system.http://www.who.int/foodsafety/publication s/capacity/en/Englsih_Guidelines_Food_control.Retriev ed 0 n $26 / 11 / 2012$.

[4] IFAD. (2009). Rota, A. and Sperandini, S. "Value chains, linking producers to the markets", in Livestock Thematic Papers: Tools for project design. Rome: International Fund for Agricultural Development (IFAD).

[5] Kaitibie S., Wanyoike F. , Kuria S. ,Brustel A. , Thendue I. N., Mwangi D. M., Omore A. (2010). Consumers' preference and willingness to pay for improved quality and safety: Case of fresh camel milk and camel meat (nyirinyiri) in Kenya.ILRI Research report No 24.
[6] KEBS. (2009). The Benchmark. The official magazine of Kenya Bureau of Standards. www.kebs.org. Retrieved on $03 / 03 / 2013$

[7] Nelson M. B. (2005). International Rules, Food Safety and the Poor Developing Country Livestock Producer, Pro-Poor Livestock Policy Initiative Working Paper No. 5. FAO, Rome. $20^{\text {th }}$ July 2005.

[8] Wanyoike F., Kaitibei S., Omore A. (2008). Can small scale actors earn higher returns from improved quality and safety animal products? www.ilri.org/publication.Retrieved on $12 / 11 / 2012$.

[9] Watson Cathy. (2010). Gender issues and pastoral economic growth and economic development in Ethiopia. Pgs. 2-4

[10] Will M and D Guenther. (2007). Food Quality and Safety Standards as required by EU Law and the Private Industry with special Reference to MEDA Countries' Exports. 